\title{
GENETIC DISSIMILARITY FOR RESISTANCE TO FOLIAR DISEASES ASSOCIATED WITH THE AGRONOMIC POTENTIAL IN MAIZE ${ }^{1}$
}

\author{
ANTÔNIA MARIA DE CÁSSIA BATISTA DE SOUSA ${ }^{2 *}$, ANDRÉ CAVALET CHAVAGLIA ${ }^{3}$, EDERSON ANTÔNIO \\ CIVARDI $^{3}$, JEFFERSON FERNANDES NAVES PINTO ${ }^{3}$, EDÉSIO FIALHO DOS REIS ${ }^{3}$
}

\begin{abstract}
In the present study the objective was to evaluate the genetic diversity among families of maize siblings for resistance to foliar diseases associated with their agronomic potential, identifying groups of families that can be used as sources of resistance in maize crop. The experiments were conducted in the experimental area of the Federal University of Goiás at the Jataí Regional Unit, in Jataí, GO, Brazil, constituted by 182 half-sibling families of maize and two commercial hybrids as a control. The 182 half-sibling families were divided into three experiments with 60,60 and 62 families, respectively. The experimental design used was randomized blocks, with three replicates. Eight quantitative characters and 4 foliar diseases were evaluated. The multivariate analysis technique was used to measure the genetic divergence for the four foliar diseases represented by the generalized Mahalanobis distance. Based on the genetic dissimilarity matrix, the dendrogram was constructed using the clustering method of the average distance between groups (Unweighted Pair Group Method with Arithmetic Mean - UPGMA). After defining the groups, univariate analysis of variance was performed in order to evaluate the effects of the groups on each character studied. Comparisons were made between the means of the groups, using the Tukey test $(p<0.05)$. White spot $(32.53 \%)$ was the disease that most contributed to the total divergence between families. Group 10 stood out among the others as a source of resistance to the disease complex associated with yield. The genetic variability of families for foliar disease complex reveals potential for future studies facing pyramiding genes.
\end{abstract}

Keywords: Genetic diversity. Genetic improvement. Multivariate analysis. Zea mays L.

\section{DISSIMILARIDADE GENÉTICA PARA RESISTÊNCIA A DOENÇAS FOLIARES ASSOCIADO AO POTENCIAL AGRONÔMICO EM MILHO}

RESUMO - No presente trabalho objetivou-se avaliar a diversidade genética entre famílias de meios irmãos de milho para resistência a doenças foliares associada ao seu potencial agronômico, identificando grupos de famílias que possam ser utilizadas como fontes de resistência na cultura do milho. Os experimentos foram conduzidos na área experimental da Universidade Federal de Goiás na Regional Jataí, em Jataí (GO), constituído por 182 famílias de meios-irmãos de milho e dois híbridos comerciais como testemunha. As 182 famílias de meios-irmãos foram divididas em três experimentos com 60,60 e 62 famílias, respectivamente. O delineamento experimental utilizado foi de blocos casualizados, com três repetições. Foram avaliados oito caracteres quantitativos e quatro doenças foliares. Foi utilizada a técnica de análise multivariada para medir a divergência genética para as quatro doenças foliares representada pela distância generalizada de Mahalanobis. Com base na matriz de dissimilaridade genética foi construído o dendrograma pelo método de agrupamento da distância média entre grupos (UPGMA). Após a definição dos grupos, realizou-se a análise de variância univariada, a fim de avaliar os efeitos dos grupos sobre cada caráter estudado. Foram realizadas comparações entre as médias dos grupos, utilizando-se do teste de Tukey $(\mathrm{p}<0,05)$. A incidência de mancha branca $(32.53 \%)$ foi a doença que mais contribuiu para a divergência total entre as famílias. $\mathrm{O}$ grupo 10 destacou-se dentre os demais como fonte de resistência para o complexo de doenças associado a produtividade. A variabilidade genética das famílias para o complexo de doenças foliares revela potencial para futuros estudos voltados para piramidação de genes.

Palavras-chave: Diversidade genética. Melhoramento genético. Análise multivariada. Zea mays L.

\footnotetext{
${ }^{*}$ Corresponding author

${ }^{1}$ Received for publication in $04 / 30 / 2020$; accepted in $08 / 11 / 2020$.

Extracted from the master's thesis of the second author

${ }^{2}$ Department of Plant Genetics and Improvement, Universidade Federal do Goiás, Goiânia, GO, Brazil; antonia.sousaufpi@gmail.com ORCID: 0000-0002-3329-1364.

${ }^{3}$ Department of Genetics and Plant Breeding, Universidade Federal de Jataí, Jataí, GO, Brazil; andrechavaglia@gmail.com - ORCID: 00000001-5010-8691, eaccivardi@yahoo.com.br - ORCID: 0000-0002-5199-3079, jeffnaves@gmail.com - ORCID: 0000-0002-8368-9135, edesiofr7@gmail.com - ORCID: 0000-0002-8000-3513.
} 


\section{INTRODUCTION}

In the perspective that involves the production chain, numerous factors contribute to reducing the yield of maize (Zea mays L.), such as problems with weeds, inadequate management, pests and diseases. In general, foliar diseases have caused serious economic damage in crops, leading to reductions of up to $30 \%$ in grain yield (CUNHA et al., 2020). According to Wordell Filho et al. (2016), the occurrence of foliar diseases in Brazil has increased mainly due to the increase of inoculum sources allied to favorable environmental conditions, promoted by the off-season sowing and the absence of crop rotation, characteristic of no-tillage.

In Brazil, the foliar diseases considered most relevant and affecting grain yield and quality are common rust (Puccinia sorghi), polysora rust (Puccinia polysora Underw); turcicum blight (Exserohilum turcicum), phaeosphaeria leaf spot or white spot (Pantoea ananatis), and gray leaf spot (Cercospora zeae-maydis) (WORDELL FILHO et al., 2016). These diseases, which are expressed under certain favorable edaphoclimatic conditions, can cause epidemics in the field and partially or totally compromise grain yield.

Given the damage caused by pathogens in maize crop, populations with resistance genes are increasingly required. Using cultivars with potential for genetic resistance to the main foliar diseases is the most viable and economical method of control (VIEIRA et al., 2009). For this, it is necessary to know the genetic variability available, as well as the type of control and inheritance of the characters involved, to identify sources of resistance to foliar diseases.

Agro-morphological evaluation provides knowledge on genetic diversity, variability and potential, maximizing the efficiency of exploitation and use of available genetic resources (RAMALHO et al., 2012). Such information is fundamental to form base populations in maize breeding programs that aim to introduce annually a large number of new hybrids with different characteristics regarding disease behavior, production potential, adaptability, stability, cycle and type of grain (TEIXEIRA et al., 2019), and, above all, in the acquisition of greater selection gains and in the exploitation of the heterosis expressed in promising hybrid combinations.

The use of multivariate techniques that facilitate the interpretation of data together is indispensable to suggest crosses between individuals belonging to different groups, but analyzing the mean of the group for the agronomic characteristics that are intended to be fixed (NICK et al. 2010). Considering the occurrence of the main foliar diseases in the present study associated with agricultural production in the region of Goiás, it is essential to perform cluster analysis to identify which characteristics are most relevant for genetic variability and which materials have potential for cultivation and to be incorporated into germplasm banks.

This study aimed to evaluate genetic diversity based on the morpho-agronomic characterization of 182 half-sibling families of maize, through the use of multivariate techniques, and indicate groups with greater potential for resistance associated with the main foliar diseases and grain yield.

\section{MATERIAL AND METHODS}

The basic material of the study originated from the diallel cross of $14 \mathrm{~F}_{2}$ populations of maize, derived from commercial hybrids from the Southwestern region of the State of Goiás (CÁRDENAS, 2005). The complete diallel scheme $(14 \mathrm{x} 14)$ was used with several agronomic characters evaluated and, among them, the resistance to Cercospora zeae-maydis. After the evaluations, five populations were selected (HG-03, HG-06, HG-09, HG-11 and HG-14) to form the RV-02 composite, used in the present study. The RV-02 composite, after recombined, was planted in an isolated lot, with free pollination, originating the 182 half-sibling families, the genetic material used in this experiment.

The experiment was conducted from February to July 2015 in the experimental area of the Federal University of Goiás, in Jataí, GO, Brazil, located at $17^{\circ} 53^{\prime} \mathrm{S}$ and $51^{\circ} 43^{\prime} \mathrm{W}$, altitude of $780 \mathrm{~m}$. Köppen's climate classification for the region is Awa, tropical savannah with rainy summer and dry winter, with average annual precipitation of approximately 1800 $\mathrm{mm}$, with higher rainfall intensity between October and April. The 182 half-sibling families were divided into three experiments with 60,60 and 62 families, respectively, each of which containing two commercial hybrids (SHS5050 and AG1051) as common controls.

The experimental design used was randomized blocks (RBD), with three replicates. The plot was represented by one $4 \mathrm{~m}$ long row, at spacing of $0.9 \mathrm{~m}$ between rows and $0.2 \mathrm{~m}$ between plants. From the measurements of the variables obtained in the experiments and as the set of families evaluated was divided into groups, with common controls, grouped analyses of variances were performed for blocks, in which the families were adjusted based on the deviations of the controls, according to Cruz, Carneiro and Regazzi (2014).

Soil tillage, weed management and 
fertilization were performed following technical recommendations for the crop in the region based on soil analysis; using basal fertilization with $250 \mathrm{~kg} \mathrm{ha}^{-1}$ of the formulation (NPK) $08-20-18$ and top-dressing fertilization with $200 \mathrm{~kg} \mathrm{ha}^{-1}$ of the formulation (NPK) 20-00-20 in the phenological stage V4. No disease control was performed.

Eight quantitative characters were evaluated: male flowering (MF) (days), female flowering (FF) (days), plant height $(\mathrm{PH})(\mathrm{m})$, ear height $(\mathrm{EH})(\mathrm{m})$, number of ears (NE) (unit), ear diameter (ED) (cm), ear length (EL) $(\mathrm{cm})$ and grain weight $(\mathrm{GW})\left(\mathrm{t}^{\mathrm{h} \mathrm{h}^{-1}}\right)$.

The following diseases were evaluated: polysora rust ( $P$. polysora); white spot ( $P$. ananatis); turcicum blight (E. turcicum); gray leaf spot (C. zeae -maydis), plus a general evaluation of the plot, referred to as foliar disease complex.

The severity of each disease, defined as the percentage of leaf area covered with symptoms of the disease, was quantified using scores: $1,2,3,4,5$, $6,7,8$ and 9 , based on the diagrammatic scale of the Agroceres Guide of Health (AGROCERES, 1996). Three evaluations were performed at 15-day intervals from the tasseling. The mean severity considered was an estimate of the mean of the disease in the plot. These values were used to calculate the area under the disease progress curve (AUDPC) (CAMPBELL; MADDEN, 1990).

To verify the genetic variability among treatments for foliar diseases, the data of AUDPC ( $P$. polysora; $P$. ananatis; E. turcicum and C. zeaemaydis) were subjected to analysis of variance. Before performing the grouped analysis considering the evaluated characters, the residual mean squares of the individual analyses were examined in the families of the three experiments, according to the maximum F test of Hartley (1950).

The study of genetic dissimilarity based on foliar disease data by means of multivariate techniques was established in order to obtain the generalized Mahalanobis distance matrix. Based on the dissimilarity matrix, cluster analysis of the genotypes was carried out using the hierarchical clustering method of the average linkage between groups (Unweighted Pair Group Method with Arithmetic Mean - UPGMA). The dendrogram was constructed to verify the degree of similarity between the genotypes under study. The cutoff point in the dendrogram was established according to the method of Mojena (1977), using the value of $\mathrm{k}=$ 1.25 as a stop rule in the definition of the number of groups. As the number of half-sibling families was high, to facilitate visualization, the dendrogram clusters were arranged in a table. The relative contribution of foliar diseases to genetic divergence was obtained by the method of Singh (1981). These analyses were performed using the computer application Genes (CRUZ, 2013).

After defining the genotype clusters, analysis of variance (univariate) was performed to evaluate the effect of the clusters on each variable studied. Then, the differences between the means of the groups, for each variable, were compared by Tukey test at 5\% probability level. These analyses were performed using the computer application SAS version 9.1.3 (SAS INSTITUTE, 2000).

\section{RESULTS AND DISCUSSION}

The maximum F ratio test or Hartley's test revealed homogeneous variances at $5 \%$ significance level for all characters of the individual analyses. Thus, a grouped variance analysis was performed. By the analysis of variance, significant differences were observed between the half-sibling families of maize evaluated, which reveal the existence of genetic variability for quantitative characters and for foliar diseases caused by $P$. polysora, $P$. ananatis, $E$. turcicum and $C$. zeae-maydis (Table 1). Therefore, there is a possibility of selection among the evaluated genotypes, with prospects of genetic gains.

The coefficients of variation (CVs) obtained were low and medium for most characters, which indicates good experimental accuracy. The CV values of these characters are within the range of the survey performed by Gurgel, Ferreira and Soares (2013), who studied the experimental accuracy in maize and bean trials, suggesting that ranges of specific variations of $\mathrm{CV}$ values should be used for each response variable when evaluating the accuracy of experiments.

The use of the UPGMA clustering method made it possible to group the 182 families and the two controls into ten distinct groups, based on the AUDPC values of the foliar diseases evaluated (Table 2). Groups 1 to 10 have 1, 2, 1, 2, 6, 5, 8, 16, 54 and 89 treatments, respectively. The formation of these groups is important in quantifying the dissimilarity between the different treatments. Families gathered in the same group indicate that they share similar characteristics and may serve as the basis for the selection of sources of resistance in breeding programs. 
A. M. C. B. SOUSA et al.

Table 1. Summary of grouped analysis of variance for the evaluated characters.

\begin{tabular}{|c|c|c|c|c|c|}
\hline \multirow{2}{*}{ Characters } & \multicolumn{3}{|c|}{ Mean Squares } & \multirow{2}{*}{$\begin{array}{c}\text { Mean } \\
\text { Families }\end{array}$} & \multirow{2}{*}{$\begin{array}{l}\text { CV } \\
(\%)\end{array}$} \\
\hline & Controls & Families & Residual & & \\
\hline PLR & $17515.68 * *$ & $4818.53 * *$ & 2533.03 & 93.64 & 53.84 \\
\hline WSP & $214621.68^{* *}$ & $29804.70 * *$ & 8713.50 & 175.63 & 52.95 \\
\hline TRB & $3864.67 * *$ & $618.34 * *$ & 289.11 & 46.60 & 36.73 \\
\hline GLS & $21407.25^{* *}$ & $5943.40^{* *}$ & 2248.32 & 97.26 & 49.39 \\
\hline FDC & $775323.78^{* *}$ & $59769.98 * *$ & 23117.25 & 440.93 & 34.67 \\
\hline $\mathrm{PH}$ & $0.64^{* *}$ & $0.02 * *$ & 0.011 & 2.03 & 5.22 \\
\hline $\mathrm{EH}$ & $0.31 * *$ & $0.01 * *$ & 0.007 & 1.08 & 7.80 \\
\hline EL & $0.22 * *$ & $1.49^{* *}$ & 0.96 & 12.79 & 7.65 \\
\hline ED & $0.01 * *$ & $0.07 * *$ & 0.03 & 3.63 & 5.17 \\
\hline $\mathrm{FF}$ & $200.00 * *$ & $6.36^{* *}$ & 2.52 & 61.98 & 2.57 \\
\hline MF & $122.72 * *$ & $6.01^{* *}$ & 1.73 & 60.44 & 2.18 \\
\hline $\mathrm{NE}$ & $0.88^{* *}$ & $32.77 * *$ & 8.85 & 15.78 & 18.67 \\
\hline GW & $3.54 * *$ & $1.37 * *$ & 0.59 & 5.20 & 14.61 \\
\hline
\end{tabular}

* and ** Significant at 5\% and 1\% probability levels, respectively, by $\mathrm{F}$ test. PLR $=$ Polysora rust - P. polysora (AUDPC); $\mathrm{WSP}=$ White spot $-P$. ananatis $($ AUDPC); TRB = Turcicum blight - E. turcicum $($ AUDPC); GLS = Gray leaf spot $-C$ zeae-maydis $(\mathrm{AUDPC}) ; \mathrm{FDC}=$ foliar disease complex $(\mathrm{AUDPC}) ; \mathrm{PH}=$ plant height $(\mathrm{m}) ; \mathrm{EH}=$ ear height $(\mathrm{m}) ; \mathrm{EL}=$ average length of 4 ears $(\mathrm{cm}) ; \mathrm{ED}=$ average diameter of 4 ears $(\mathrm{cm}) ; \mathrm{FF}=$ female flowering (days); $\mathrm{MF}=$ male flowering (days); $\mathrm{NE}=$ number of ears in $4 \mathrm{~m}$; and $\mathrm{GW}=$ grain weight $\left(\mathrm{t} \cdot \mathrm{ha}^{-1}\right)$.

Table 2. Groups formed in the dendrogram obtained by the hierarchical method of average linkage between groups (UPGMA) of 182 half-sibling families and two controls of $Z$. mays, using Mahalanobis distance, based on the area under the progress curve related to foliar diseases caused by: P. polysora; P. ananatis; E. turcicum and C. zeae-maydis.

\begin{tabular}{|c|c|}
\hline Groups & Families \\
\hline 1 & 24 \\
\hline 2 & 72117 \\
\hline 3 & 52 \\
\hline 4 & 3336 \\
\hline 5 & 15164483143178 \\
\hline 6 & 33456140144 \\
\hline 7 & 236286122126145166181 \\
\hline 8 & 67910192629304855576069136161165 \\
\hline 9 & $\begin{array}{c}12172235373839414751596164656668717784879293949697102108111113 \\
114115120121124127130131132133139141146148152154155162164171179180 \\
182183\end{array}$ \\
\hline 10 & $\begin{array}{c}4581112131418202125272831324042434546495053545863677073747576 \\
78798081828588899091959899100101103104105106107109110112116118119 \\
123125128129134135137138142147149150151153156157158159160163167168 \\
169170172173174175176177184\end{array}$ \\
\hline
\end{tabular}

${ }^{*}$ cophenetic correlation coefficient $=0.778$. 
A. M. C. B. SOUSA et al.

The hybrid AG1051 (184 family), considered tolerant to gray leaf spot, was positioned in group 10 and the hybrid SHS5050 (family 183), considered medium susceptible, was in group 9 . The positioning of these hybrids in different groups shows that they have differential characteristics for the set of foliar diseases.

The cophenetic correlation coefficient for the hierarchical clustering method UPGMA was 0.778 and significant at $1 \%$ probability level. This coefficient can be used to evaluate the consistency of the clustering pattern by hierarchical methods, where values close to one (1.00) indicate better representativeness (CRUZ; CARNEIRO; REGAZZI, 2014). Therefore, the dendrogram expressed a strong relationship between the matrices.

For the UPGMA hierarchical clustering method, the lowest mean distances between groups 9 and 10 (81.37), 8 and 9 (149.73) and 8 and 10 (170.62) were verified (Table 3). Thus, the crossing between plants of these pairs of groups is not indicated when the exploration of heterosis is the main target.

Table 3. Intra- and intergroup means of Mahalanobis distance in 182 half-sibling families of maize and two controls grouped by the UPGMA method, based on the area under the progress curve related to foliar diseases caused by: $P$. polysora; P. ananatis; E. turcicum and C. zeae-maydis.

\begin{tabular}{|c|c|c|c|c|c|c|c|c|c|c|}
\hline Group & 1 & 2 & 3 & 4 & 5 & 6 & 7 & 8 & 9 & 10 \\
\hline 1 & 0.00 & 1227.75 & 1331.43 & 477.42 & 757.36 & 1309.75 & 2040.38 & 767.11 & 1108.35 & 1369.51 \\
\hline 2 & & 3.07 & 588.96 & 572.27 & 654.78 & 414.55 & 368.10 & 513.91 & 228.29 & 459.98 \\
\hline 3 & & & 0.00 & 585.08 & 819.22 & 482.75 & 393.48 & 493.11 & 481.05 & 623.60 \\
\hline 4 & & & & 3.87 & 292.38 & 452.20 & 884.55 & 216.18 & 350.28 & 424.93 \\
\hline 5 & & & & & 2.32 & 253.33 & 822.53 & 230.98 & 375.05 & 358.66 \\
\hline 6 & & & & & & 3.44 & 316.59 & 422.79 & 315.39 & 368.01 \\
\hline 7 & & & & & & & 3.02 & 595.57 & 302.34 & 356.51 \\
\hline 8 & & & & & & & & 2.29 & 149.73 & 170.62 \\
\hline 9 & & & & & & & & & 3.06 & 81.37 \\
\hline 10 & & & & & & & & & & 3.16 \\
\hline
\end{tabular}

*182 half-sibling families of maize and two controls.

The mean distances were higher between the group pairs 1 and 7 (2040.38), 1 and 10 (1369.51) and 1 and 3 (1331.43) (Table 3). Therefore, these pairs of groups are considered the most divergent for the four foliar diseases evaluated. Crosses between families of these groups may be indicated to increase the variability and the possibility of expression of the heterotic effect, which are desirable in a genetic improvement program.

The genetic variability of the host, in the case of families, is one of the factors that contribute to the durability of resistance to different races of a pathogen (CASELA, 2005), because the higher the genetic variability, the greater the number of alleles determining variation in characteristics and the greater the chances of an allele to positively respond to environmental changes. This contributes to the development of cultivars with durable resistance, remaining effective as long as a cultivar is widely cultivated in one or more environments favorable to the disease.

The univariate analysis of variance was significant at $1 \%$ probability level for all evaluated characteristics. This result is an indication that the cluster analysis was able to discriminate accessions in dissimilarities groups. Considering the means of the groups formed, the coefficients of variation $(\mathrm{CV} \%)$ obtained were low and medium for all characters, which demonstrates a good experimental accuracy, giving reliability to the results obtained and the conclusions drawn (Table 4).

The use of univariate analysis of variance among the means of groups obtained after multivariate analysis has been widely used (ALVES; REIS; PINTO, 2012; PROTÁSIO et al., 2017; REIS et al., 2017; REIS et al., 2019) in order to facilitate the selection of promising materials, by comparing means between groups by the Tukey test.

The lowest values of AUDPC for white spot and for gray leaf spot are located in group 10, while for polysora rust are found in groups 2 and 7 and for turcicum blight in groups 1 and 5 (Table 4). This makes it clear that there are difficulties in aggregating in the same genotype resistance to the complex of foliar diseases evaluated, that is, lower AUDPC for the four diseases in the same group of genotypes. However, this highlights potential families that can be used to develop gene pyramiding or with specific recommendation for certain epidemics. 
A. M. C. B. SOUSA et al.

Table 4. Univariate analysis of variance and comparison of means of groups formed from the cluster analysis.

\begin{tabular}{ccccccc}
\hline Variables & & PLR & WSP & TRB & GLS & FDC \\
\hline \multirow{2}{*}{ ANOVA } & mean & 123.08 & 253.98 & 56.17 & 139.42 & 538.79 \\
& CV $(\%)$ & 7.40 & 8.85 & 6.32 & 6.80 & 6.65 \\
& MS & $407727.13^{* *}$ & $1490538.61^{* *}$ & $38912.98^{* *}$ & $370215.09^{* *}$ & $1242383.68^{* *}$ \\
\hline \multirow{5}{*}{ Mean of groups } & 1 & $249.73 \mathrm{a}$ & $522.67 \mathrm{a}$ & $36.25 \mathrm{~g}$ & $242.51 \mathrm{a}$ & $780.81 \mathrm{a}$ \\
& 2 & $42.17 \mathrm{~h}$ & $424.67 \mathrm{~b}$ & $43.28 \mathrm{de}$ & $103.34 \mathrm{e}$ & $592.99 \mathrm{bc}$ \\
& 3 & $177.65 \mathrm{~b}$ & $246.42 \mathrm{e}$ & $98.58 \mathrm{a}$ & $103.59 \mathrm{e}$ & $601.81 \mathrm{~b}$ \\
& 4 & $180.92 \mathrm{~b}$ & $268.87 \mathrm{~d}$ & $59.03 \mathrm{c}$ & $187.30 \mathrm{~d}$ & $584.65 \mathrm{~cd}$ \\
& 6 & $120.18 \mathrm{~d}$ & $155.00 \mathrm{~h}$ & $40.17 \mathrm{f}$ & $213.29 \mathrm{~b}$ & $456.67 \mathrm{~g}$ \\
& 7 & $74.01 \mathrm{f}$ & $170.38 \mathrm{~g}$ & $75.96 \mathrm{~b}$ & $202.30 \mathrm{c}$ & $530.10 \mathrm{e}$ \\
& 8 & $55.76 \mathrm{~g}$ & $161.89 \mathrm{gh}$ & $77.32 \mathrm{~b}$ & $85.07 \mathrm{~g}$ & $414.30 \mathrm{~h}$ \\
& 9 & $167.07 \mathrm{c}$ & $189.37 \mathrm{f}$ & $42.86 \mathrm{e}$ & $101.13 \mathrm{e}$ & $503.45 \mathrm{f}$ \\
& 10 & $80.36 \mathrm{e}$ & $283.60 \mathrm{c}$ & $44.91 \mathrm{~d}$ & $93.93 \mathrm{f}$ & $567.75 \mathrm{~d}$ \\
\hline
\end{tabular}

$*$ and $* *$ Significant at $5 \%$ and $1 \%$ probability levels, respectively by the $\mathrm{F}$ test. ${ }^{1}$ Means followed by equal letters in the row do not differ by Tukey test $(\mathrm{p}<0.05)$. PLR $=$ Polysora rust $-P$. polysora $($ AUDPC); WSP $=$ White spot $-P$. ananatis $($ AUDPC); TRB = Turcicum blight - E. turcicum $($ AUDPC); GLS = Gray leaf spot - C. zeae-maydis $($ AUDPC); FDC = foliar disease complex (AUDPC).

Lower mean values for the foliar disease complex indicate greater resistance to the evaluated diseases (Table 4). Thus groups can be classified according to their resistance as follows: $10(355.36)$ $>7(414.30)>5(456.67)>8(503.45)>6(530.10)$ $>9(567.75)=4(584.65)>2(592.99)>3(601.81)$ $>1(780.81)$.

Group 10, composed of 89 families including the hybrid AG1051, has the lowest value of AUDPC for the complex of the evaluated diseases (355.36). Therefore, this group has greater potential among the others to be used as a source of resistance to these diseases in future genetic improvement studies. Group 1 had the highest values of AUDPC for most of the evaluated diseases, except for turcicum blight (Table 4). Thus, it is the group that presents families with greater susceptibility. However, it can be used in studies aimed at sources of resistance to turcicum blight.

Groups 1 (780.81) and 2 (592.99) were the first and third most susceptible to the foliar disease complex evaluated (Table 4). This may have contributed to its low yield, considering that these groups are among the three with the lowest mean value for grain weight (Table 5). According to Casela, Ferreira and Pinto (2006), in cases of more severe attacks of the foliar disease complex affecting maize, significant damage to plants may occur due to malfunction and destruction of photosynthetic tissues, causing reduction in grain yield.

The highest means of ear diameter and length were 4.60 and $16.08 \mathrm{~cm}$, obtained by groups 3 and 10 , respectively. Group 1 had lower means $(4.4 \mathrm{~cm}$ and $14.45 \mathrm{~cm})$ for both characteristics. The high susceptibility of group 1 to foliar diseases may have led to this result, reducing the development of such characteristics. According to Wordell Filho et al. (2016), the attack of foliar diseases can reduce the yield components of the crop (ear size, number of grains per ear and grain weight). Ciampitti et al. (2015) state that damage caused by diseases is one of the potential factors affecting ear development.

For the male and female flowering characters, the highest means were 62.34 and 63.97 days, respectively, both found in group 7, while the lowest means for male and female flowering were 59.99 and 61.41 days, respectively, in group 5. Plants that bloom even under favorable climatic conditions with a longer flowering interval are more prone to low grain yield due to the non-synchronization in pollen release and the receptivity of stigmas for ovary fertilization and grain development (NGUGI et al., 2013). Therefore, maize breeding programs are focused on earlier plants with a shorter flowering interval (EDWARDS, 2011). This can be verified in both groups, considering that they have high mean values of yield, which may be associated with the short flowering interval.

Group 5 was the third most resistant to the disease complex (456.67) and had a high mean value of grain weight $\left(6.02\right.$ t.ha $\left.^{-1}\right)$. Despite showing high values for gray leaf spot (213.29) and polysora rust (120.18), it was able to achieve higher mean grain weight $\left(6.0 \mathrm{t}^{\mathrm{h} \mathrm{h}^{-1}}\right)$ than group $10\left(5.28 \mathrm{t}^{\mathrm{h}} \mathrm{ha}^{-1}\right)$. This indicates that such diseases can cause less damage and yield losses compared to white spot and turcicum blight. 
A. M. C. B. SOUSA et al.

Table 5. Univariate analysis of variance and comparison of means of groups formed from the cluster analysis.

\begin{tabular}{|c|c|c|c|c|c|}
\hline \multicolumn{2}{|c|}{ Variables } & \multirow{2}{*}{$\frac{\mathrm{PH}}{2.11}$} & \multirow{2}{*}{$\frac{\mathrm{EH}}{1.10}$} & \multirow{2}{*}{$\frac{\text { EL }}{14.46}$} & \multirow{2}{*}{$\frac{\mathrm{ED}}{4.52}$} \\
\hline & Mean & & & & \\
\hline ANOVA & CV (\%) & 1.59 & 2.39 & 1.95 & 1.31 \\
\hline \multirow{11}{*}{ Mean of groups } & MS & $0.37^{* *}$ & $0.14^{* *}$ & $364.29^{* *}$ & $3.21^{* *}$ \\
\hline & 1 & $2.15 b$ & $1.11 \mathrm{c}$ & $14.45 \mathrm{~g}$ & $4.44 f$ \\
\hline & 2 & $2.11 \mathrm{c}$ & $1.06 \mathrm{~g}$ & $14.76 \mathrm{f}$ & $4.48 \mathrm{e}$ \\
\hline & 3 & $2.22 \mathrm{a}$ & $1.19 \mathrm{a}$ & $15.54 \mathrm{~d}$ & $4.60 \mathrm{a}$ \\
\hline & 4 & $2.06 \mathrm{e}$ & $1.11 \mathrm{~cd}$ & $15.31 \mathrm{e}$ & $4.51 \mathrm{~cd}$ \\
\hline & 5 & $2.07 \mathrm{de}$ & $1.08 \mathrm{f}$ & $15.83 \mathrm{bc}$ & $4.50 \mathrm{~d}$ \\
\hline & 6 & $2.15 b$ & $1.13 b$ & $15.89 \mathrm{~b}$ & $4.55 \mathrm{c}$ \\
\hline & 7 & $2.16 \mathrm{~b}$ & $1.09 \mathrm{de}$ & $15.58 \mathrm{~d}$ & $4.53 \mathrm{~cd}$ \\
\hline & 8 & $2.09 \mathrm{~d}$ & $1.09 \mathrm{ef}$ & $15.44 \mathrm{de}$ & $4.51 \mathrm{~d}$ \\
\hline & 9 & $2.02 \mathrm{f}$ & $1.05 \mathrm{~g}$ & $15.74 \mathrm{c}$ & $4.49 \mathrm{de}$ \\
\hline & 10 & $2.03 \mathrm{f}$ & $1.08 \mathrm{f}$ & $16.08 \mathrm{a}$ & $4.58 \mathrm{~b}$ \\
\hline \multicolumn{2}{|c|}{ Variables } & $\mathrm{FF}$ & MF & $\mathrm{NE}$ & GW \\
\hline \multirow{3}{*}{ ANOVA } & Mean & 62.12 & 60.82 & 16.96 & 5.45 \\
\hline & CV (\%) & 0.79 & 0.76 & 6.85 & 4.46 \\
\hline & MS & $47.22^{* *}$ & $42.11^{* *}$ & $120.13^{* *}$ & $25.93^{* *}$ \\
\hline \multirow{10}{*}{ Mean of groups } & 1 & $62.15 b c$ & $60.82 \mathrm{c}$ & $17.03 \mathrm{c}$ & $5.50 \mathrm{~d}$ \\
\hline & 2 & $61.86 \mathrm{e}$ & $61.09 b$ & $17.36 \mathrm{c}$ & $5.02 \mathrm{f}$ \\
\hline & 3 & $61.82 \mathrm{e}$ & $60.16 \mathrm{~d}$ & $19.03 \mathrm{a}$ & $6.14 \mathrm{a}$ \\
\hline & 4 & $62.02 \mathrm{~cd}$ & $61.10 \mathrm{~b}$ & $17.03 \mathrm{c}$ & $4.30 \mathrm{~g}$ \\
\hline & 5 & $61.41 \mathrm{f}$ & $59.99 \mathrm{~d}$ & $16.20 \mathrm{~d}$ & $6.02 b$ \\
\hline & 6 & $62.35 b$ & $61.22 \mathrm{~b}$ & $18.35 b$ & $5.89 \mathrm{c}$ \\
\hline & 7 & $63.97 \mathrm{a}$ & $62.34 \mathrm{a}$ & $15.66 \mathrm{~d}$ & $5.56 \mathrm{~d}$ \\
\hline & 8 & $61.36 f$ & $60.13 d$ & $16.98 \mathrm{c}$ & $5.50 \mathrm{~d}$ \\
\hline & 9 & $61.98 \mathrm{de}$ & $60.64 \mathrm{c}$ & $16.89 \mathrm{c}$ & $5.19 \mathrm{e}$ \\
\hline & 10 & $62.24 \mathrm{bc}$ & $60.75 \mathrm{c}$ & $15.10 \mathrm{e}$ & $5.28 \mathrm{e}$ \\
\hline
\end{tabular}

$*$ and ** Significant at $5 \%$ and $1 \%$ probability levels, respectively by the $\mathrm{F}$ test. ${ }^{1}$ Means followed by equal letters in the row do not differ by Tukey test $(\mathrm{p}<0.05) . \mathrm{PH}=$ plant height $(\mathrm{m}) ; \mathrm{EH}=$ ear height $(\mathrm{m})$; EL = average length of 4 ears $(\mathrm{cm})$; $\mathrm{ED}=$ average diameter of 4 ears $(\mathrm{cm}) ; \mathrm{FF}=$ female flowering (days); $\mathrm{MF}=$ male flowering (days); $\mathrm{NE}=$ number of ears in $4 \mathrm{~m}$; and $\mathrm{GW}=$ grain weight $\left(\mathrm{t} \cdot \mathrm{ha}^{-1}\right)$.

Group 5 had the second lowest value of AUDPC (155.0) for white spots and is statistically equal to group 7. Among these groups, the families of group 5 should be considered for selection purposes because they show lower severity of the disease associated with earlier cycle, desirable characteristics in plant improvement.

Group 3 had the highest mean value of ear height $(1.19 \mathrm{~m})$ and higher mean value of grain weight $\left(6.14\right.$ t.ha $\left.^{-1}\right)$, formed by only one family. This family is highlighted because it obtained high yield despite being part of the second most susceptible group to all diseases, demonstrating that it is tolerant to the evaluated diseases. According to Wang et al. (2016), plants with similar heights, but with shorter ear height, are expected to be more resistant to lodging and/or breakage. The ear acts as a pendulum under the action of winds and rains and, as the plant reaches maturity and begins the drying period, the stem becomes more fragile, causing plants that have higher ears to come to lodge or break because they cannot sustain the ear weight (CRISPIM FILHO, 
2018).

The method of Singh (1981), used to estimate the relative contribution of each character in the expression of genetic divergence, indicated that white spot $(32.53 \%)$ was the foliar disease that most contributed to the total divergence between 182 halfsibling families of maize and two controls. The incidence of turcicum blight was the one that contributed the least $(20.30 \%)$ among the four diseases evaluated (Table 6). The multivariate analysis technique has the advantage over univariate analysis methods of evaluating the importance of each characteristic studied on the total variation available among the evaluated genotypes, making it possible to disregard less discriminant characters (MARTINELLO et al., 2002). Thus, the incidence of turcicum blight is the one most prone to be disregarded to verify the presence of genetic variability in the families evaluated in the present study.

Table 6. Relative contribution of four foliar diseases evaluated in 182 half-sibling families of maize and two controls, using the methodology of Singh (1981), based on the generalized Mahalanobis distance.

\begin{tabular}{cc}
\hline \multirow{2}{*}{ Variables } & Relative contribution \\
\cline { 2 - 2 } & s.j (\%) \\
\hline PLR & 22.55 \\
WSP & 32.53 \\
TRB & 20.30 \\
GLS & 24.62 \\
\hline
\end{tabular}

$\mathrm{PLR}=$ Polysora rust $-P$. polysora $($ AUDPC $) ; \mathrm{WSP}=$ White spot $-P$. ananatis $($ AUDPC); TRB $=$ Turcicum blight $-E$. turcicum (AUDPC); GLS = Gray leaf spot - C. zeae-maydis (AUDPC).

\section{CONCLUSIONS}

Wide phenotypic variability was observed among the half-sibling families, enabling the formation of ten distinct and heterogeneous groups.

Group 10 families have the potential to be used in breeding programs as a source of resistance to the complex of diseases evaluated associated with yield. On the other hand, group 1 families are considered more susceptible to the complex of foliar diseases associated with low agronomic performance. The foliar diseases gray leaf spot and polysora rust caused less damage and yield losses compared to white spot and turcicum blight. The genetic variability among families for the foliar disease complex serves as a basis for the development of future studies for gene pyramiding.

\section{ACKNOWLEDGMENTS}

To CAPES - Coordination for the Improvement of Higher Education Personnel, for the financial support; to FAPEG - Goiás State Research Support Foundation, for the financial support; and to UFJ - Federal University of Jataí.

\section{REFERENCES}

ALVES, R. C; REIS, E. F; PINTO, J. F. N. Genetic divergence in pepper genotypes from southwest Goiás. Ciência e Agrotecnologia, 36: 498-506, 2012.
AGROCERES. Guia Agroceres de sanidade. Sementes Agroceres, São Paulo, 1996. 72 p.

CAMPBELL, C. L; MADDEN, L. V. Introduction to plant disease epidemiology. John Willey \& Sons, Nova York, Brasil, 1990. 532 p.

CÁRDENAS, F. E. N. Valor genético de populações de milho adaptadas para a região sudoeste de Goiás. 2005. 169 f. Dissertação (Mestrado em Genética e Melhoramento de Plantas) - Escola Superior de Agricultura "Luiz de Queiroz", Piracicaba, 2005.

CASELA, C. R. Variabilidade genética de patógenos e resistência de cultivares. In: SEMINÁRIO NACIONAL DE MILHO SAFRINHA, 8., 2005, Campinas. Anais... Campinas: IAC, 2005. p. 19 189194.

CASELA, C. R.; FERREIRA, A. S.; PINTO, N. F. J. A. Doenças na cultura do milho. Embrapa Milho e Sorgo-Circular Técnica (INFOTECA-E), 2006. Disponível em: <https:// www.infoteca.cnptia.embrapa.br/bitstream/ doc/490415/1/Circ83.pdf> Acesso em: 23 mai. 2019.

CIAMPITTI, I. et al. Anormalidades em espigas de milho. 1. ed. Kansas, Missouri: K-State Research and Extension, 2015, 15 p.

CRISPIM FILHO, A. J. Estimação de parâmetros genéticos e análise de trilha em uma população de milho com potencial para seleção recorrente. 2018. 99 f. Dissertação (Mestrado em Genética e 
Melhoramento de Plantas) Universidade Federal do Goiás, Goiânia, 2018.

CRUZ, C. D. Genes - a software package for analysis in experimental statistics and quantitative genetics. Acta Scientiarum, 35: 271-276, 2013.

CRUZ, C. D.; CARNEIRO, P. C. S.; REGAZZI, A. J. Modelos biométricos aplicados ao melhoramento genético. 3. ed. rev. e ampl. Viçosa, MG: Ed. UFV, 2014. v. 2, 668 p.

CUNHA, B. A. D. et al. Influência da época de semeadura na severidade de doenças foliares e na produtividade do milho safrinha. Summa Phytopathologica, 45: 424-427, 2020.

EDWARDS, J. Changes in plant morphology in response to recurrent selection in the Iowa Stiff Stalk Synthetic maize population. Crop Science, 51: 2352 $-2361,2011$.

GURGEL, F. L.; FERREIRA, D. F.; SOARES, A. C. $S$. O coeficiente de variação como critério de avaliação em experimentos de milho e feijão. Embrapa Amazônia Oriental. Boletim de Pesquisa e Desenvolvimento (INFOTECA-E), 2013. 120 p. Disponível em: <https:// www.infoteca.cnptia.embrapa.br/infoteca/handle/ doc/955896>. Acesso em 20 mai. 2019.

HARTLEY, H. O. The use of range in analysis of variance. Biometrika. 37: 271-280, 1950.

MARTINELLO, G. E. et al. Divergência genética em acessos de quiabeiro com base em marcadores morfológicos. Horticultura Brasileira, 20: 52-58, 2002.

MOJENA, R. Hierarchical grouping methods and stopping rules: an evaluation. The Computer Jornal, 20: 359-363, 1977.

NGUGI, K. et al. Anthesis to silking interval usefulness in developing drought tolerant maize. Jornal of Renewable Agriculture, 84: 90-90, 2013.

NICK, C. et al. Divergência genética entre subamostras de mandioca. Bragantia, 69: 289-298, 2010 .

PROTÁSIO, T. P. et al. Classificação de clones de Eucalyptus por meio da relação siringil/guaiacil e das características de crescimento para uso energético. Scientia Florestalis, 45: 327-341, 2017.

RAMALHO, M. A. P et al. Aplicações da genética quantitativa no melhoramento de plantas autógamas. 1.ed. Lavras, MG: UFLA, 2012. 522 p.

REIS, E. F. et al. Characteristicas of 137 macaw palm (Acrocomia aculeata) fruit accessions from Goias, Brazil. Comunicata Scientiae, 10: 117-124, 2019

REIS, E. F. et al. Genetic diverstiy of macaúba fruits from 35 municipalities of the state of Goiás, Brazil. Pesquisa Agropecuária Brasileira. Brasília, 52: 277-282, 2017

SAS INSTITUTE (Cary, Estados Unidos). SAS/ STAT user's guide. Cary, 2000. CD-ROM

SINGH, D. The relative importance of characters affecting genetic divergence. Indian Journal of Genetics and Plant Breeding, 41: 237-245, 1981.

TEIXEIRA, F. F. et al. Diversidade genética entre acessos do Banco Ativo de Germoplasma de Milho com grãos brancos do tipo dentado. Embrapa Milho e Sorgo-Documentos (INFOTECA-E), 2019. Disponível em: <https:// www.infoteca.cnptia.embrapa.br/infoteca/handle/ doc/1111013>. Acesso em 30 jan. 2020.

VIEIRA, R. A et al. Resistência de híbridos de milho -pipoca a Exserohilum turcicum, agente causal da helmintosporiose do milho. Scientia Agraria, 10: 391-395, 2009.

WANG, H. et al. Heterotic loci identified for plant height and ear height using two CSSLs test populations in maize. Journal of Integrative Agriculture, 15: 2726-2735, 2016.

WORDELL FILHO, J. A. et al. Pragas e doenças do milho: diagnose, danos e estratégias de manejo. Florianópolis: Epagri, 2016. Disponível em: <http://ciram.epagri.sc.gov.br/ciram arquivos/ arquivos/agroconnect/boletins/

BT_PragasDoencasMilho.pdf $>$. Acesso 15 ago. 2018 . 